\title{
Studying the impact of different additives on the properties of straight-run diesel fuels with various hydrocarbon compositions
}

\author{
Maria Kirgina, Ilya Bogdanov, Andrey Altynov, Nataliya Belinskaya*, Alina Orlova, and Nurguyaana Nikonova \\ School of Earth Sciences \& Engineering, Tomsk Polytechnic University, 634050 Tomsk, Russia
}

Received: 6 December 2020 / Accepted: 29 March 2021

\begin{abstract}
One of the most widely used way to improve low-temperature properties of diesel fuels is the use of additives. However, a variety of additives and the effect of susceptibility make it difficult to select additive for a particular composition of diesel fuel and operating conditions. The laws of interaction between functional groups of additives and hydrocarbons of the diesel fraction have not been investigated yet. The article discusses the influence of fractional, group and structural-group composition of straight-run diesel fuels on the effectiveness of cold flow improvers. The effect of additives concentration on the effectiveness of their action is considered. It was shown that when selecting a cold flow improver for diesel fuel and determining its optimal concentration, it is necessary to take into account the optimal content of various groups of hydrocarbons in diesel fuel, at which a cold flow improver is most effective.
\end{abstract}

\section{List of Symbols}

$C_{\mathrm{al}} \quad$ Mass fraction of carbon in alkyl substituents, $\%$ wt.

$C_{\text {ar }} \quad$ Mass fraction of carbon in aromatic rings, $\%$ wt.

$\mathrm{CI}_{\text {ISO }} \quad$ Cetane Index proposed by the ISO 42642008 "Petroleum products - Calculation of cetane index of middle-distillate fuels by the four-variable equation", points, ${ }^{\circ} \mathrm{C}$

$C_{\mathrm{n}} \quad$ Mass fraction of carbon in naphthenic structures, \% wt.

$C_{\mathrm{r}} \quad$ Mass fraction of carbon in ringed structures, $\%$ wt.

$K, K_{1} \quad$ Aniline coefficients

$K_{\text {ar }} \quad$ Number of aromatic rings

$K_{\mathrm{n}} \quad$ Number of naphthenic rings

$K_{\text {tot }} \quad$ Total number of rings

$T_{\text {cp }} \quad$ Cloud Point, ${ }^{\circ} \mathrm{C}$

$T_{\mathrm{pp}} \quad$ Pour Point, ${ }^{\circ} \mathrm{C}$

\section{Introduction}

In many countries, due to the climate conditions, it is important not only to produce high-quality and environmentally friendly petroleum products, but also to provide

\footnotetext{
* Corresponding author: belinskaya@tpu.ru
}

diesel fuels capable of maintaining their performance in cold conditions. In addition, the development of the Arctic and Antarctic territories is one of the strategic directions for the development of a number of countries (Russian Federation, Canada, USA, Northern Europe countries). Achieving success in these tasks is impossible without provision of diesel fuel, available to operate in cold conditions in internal combustion engines and machines, including those used to generate electricity [1-4].

Production of low-freezing high-quality diesel fuel grades is being complicated from year to year as far as the raw material for oil refineries deteriorates due to the involvement of heavy, high-sulfur oil and fractions [5-9].

There are various ways to improve low-temperature properties of diesel fuel (the cloud point, the pour point and the Cold Filter Plugging Point (CFPP)). However, the use of cold flow improvers (depressant, dispersant and depressant-dispersant) is the most common and the most cost-effective way [10-12].

Depressant additives interact with the surface of the incipient crystals and prevent their growth and association. The mechanism of the depressant action has not been conclusively established. Two opinions are the most common. First opinion suggests the adsorption of the depressant on the surface of the paraffin crystal, second opinion suggests the co-crystallization of the paraffin and the depressant. During adsorption, the depressant molecule is adsorbed on the crystal surface by the polar part, non-polar part faces the fuel medium and prevents agglomeration of the paraffin crystals and their association into an ordered structure. During co-crystallization, on the contrary, the depressant 
molecule is embedded by the non-polar part in the paraffin crystal, and the polar parts, that remain outside, prevent settling of new paraffin molecules on the surface of the crystal, ensuring prevention of its further growth.

Compare to other types of fuel, diesel fuel, largely varies in hydrocarbon composition depending on the raw materials and production technology. At the same time, the use of additives is not a universal way to improve fuel lowtemperature properties, since in most cases there is a need to select individual additive compositions for each individual batch of fuel. This is due to the variety of additive compositions existing on the market, which distinguish between the active components, the required concentrations, etc. Moreover, the interaction of hydrocarbons of diesel fraction with the components of cold flow improvers contributes the efficiency of the additive. These interactions are of a colloid-chemical nature and cause the effect of susceptibility of cold flow improvers, i.e. different effects of the same additive on the low-temperature properties of diesel fuels of different composition; the existence of the limiting additive concentration, the excess of which does not change low-temperature properties of the fuel. In this connection, the problem of a rational selection of additives and its concentrations, taking into account the effect of susceptibility, is essential.

A large number of research papers are devoted to the synthesis of the new high-performance cold flow improvers. The main acting components in the developed additives are polymers, such as a binary alternating polymer based on maleic anhydride and vinyl acetate [13], amidopolyformaldehyde [14], methacrylate-co-maleic anhydride [15], nanohybrid poly (tetradecyl-methyl-acrylate)-grafene oxide [16], polymethyl acrylate, ethylene poly- $\alpha$-olefin [17], vinyl acetate copolymer [18, 19], a tetrapolymer consisting of methacrylates with maleic anhydride and methacrylic morpholine and their amine compounds [19], n-alkyl acrylate-vinyl acetate-styrene-ternary copolymer [20], dialkyl fumarate-styrene-vinyl acetate-terpolymer [21], dimethyl fumarate-vinyl acetate copolymer [22], dimeric surfaceactive substances [23]. Polymeric additives improve pumpability of diesel fuel by change the crystalline structure of wax crystals which tend to solidify at low temperatures and block fuel filters. Due to containing a polar functional group, cold flow improvers provide wax crystals being more compact, regular, and uniformly arranged [24]. These ensure a liquid state of the fuel.

One of the ways, which is used to improve cold flow properties of diesel fuel is mixing with kerosene [25-29]. This way has a number of disadvantages, such as deterioration of diesel fuel quality, namely decreasing of the cetane number, viscosity, flash point, increasing of engine wear. Moreover, there is a difficulty in selecting optimal composition of diesel fuel meeting specifications on fractional composition (the indicator: no more $10 \%$ vol. boiled lower that $180{ }^{\circ} \mathrm{C}$ ). This method does not eliminate the use of cold flow improvers as well.

Cold flow improvers not only provide flow ability of diesel fuels, but also improve their oxidation stability due to their capability to release a proton of polar functional group and prevention of free radicals formation, as well as neutralization of carboxylic acids [30]. Moreover, cold flow improvers can be used to enhance lubricity of diesel fuels [31].

In [32] Cheng et al. studied the compatibility of various additives with respect to the CFPP of diesel fuel. Diesel fuel was analyzed by X-Ray Diffraction and gas chromatography, the carbon number distribution of wax crystals was determined. It was found that due to the precipitation of the low carbon atom n-paraffins and formation of the fine crystal particles with the certain wax crystals, the flow ability of diesel fuel is improved in two cases: the first case is when the cold flow improver was added to the diesel fuel, the second case is when the cold flow improver and the flow aid were added to the diesel fuel.

By considering a large number of additives having different composition and structure, Han et al. have found that the most effective additive is one that contains significant amount of aromatic compounds, which provide good solubility and dispersion of the additive and thus increase its efficiency in improving low-temperature properties [33].

The studies were also conducted on the effect of the amount of additive on the low-temperature properties of the various fuels, not only the diesel fuel. The works [34-36] consider the effect of the amount of pour point depressant on the low-temperature properties of fuel oil. The authors [37] showed the possibility of obtaining lowviscosity marine fuel of winter and grades with improved low-temperature properties using pour point depressants. Cold flow improvers were also synthesized and effectively used as the pour point depressants for the lube oils [38-42].

Despite a large number of works, studying the effect of additives on diesel fuel low-temperature properties, most of them are devoted to the synthesis of additives, the analysis of the effectiveness of which does not include research on fuels of various compositions. Only a limited number of works $[43,44]$ consider the composition of diesel fuel as a factor influencing the effectiveness of cold flow improvers.

Thus, the aim of this work is to study the effect of hydrocarbon composition (fractional, group, structuralgroup) of straight-run diesel fuels on the effectiveness of cold flow improvers.

\section{Experimental}

\subsection{Materials}

In this study, 5 samples of straight-run diesel fuel derived from Western Siberia oil (the Russian Federation), were selected as the objects of the study. Samples were assigned numerical ciphers from 1 to 5 .

Straight-run diesel fuels were selected due to their properties and composition, which differ from those diesel fuels derived from the secondary processes. Straight-run diesel fuels, as a rule, are characterized by poor low-temperature properties and a high content of n-paraffins. In work [45] the composition of 41 diesel fuel samples was determined by flow modulated two-dimensional gas chromatography with flame ionization detection. According to the obtained results, the content of $\mathrm{n}$-paraffins in the diesel fuel samples 
Table 1. Composition, properties of the cold flow improvers and producer's recommendations for their use.

\begin{tabular}{llll}
\hline Characteristics & \multicolumn{3}{c}{ Cold flow improver } \\
\cline { 2 - 4 } Composition & \multicolumn{1}{c}{$\mathrm{A}$} & \multicolumn{1}{c}{$\mathrm{B}$} & \multicolumn{1}{c}{$\mathrm{C}$} \\
& $\begin{array}{l}\text { Ethylene copolymers, } \\
\text { vinyl ether, acrylates, } \\
\text { ethylene glycol complex }\end{array}$ & $\begin{array}{l}\text { Ligroin, vinyl acetate, } \\
\text { naphthalene, } \\
\text { ethylbenzene }\end{array}$ & $\begin{array}{l}\text { Hydrocarbons } \mathrm{C}_{10}-\mathrm{C}_{13} \text {, paraffins, } \\
\text { aromatic hydrocarbons, cycloalkanes, } \\
\text { naphthalene, combination of various } \\
\text { high-molecular weight ashless chemical } \\
\text { compounds }\end{array}$
\end{tabular}

Producer's

recommendations
Using $1 \mathrm{~mL}$ of the asing 150 mL of the additive per $1 \mathrm{~L}$ of fuel additive to $65 \mathrm{~L}$ of fuel lowers the pour point for lowers CFPP to $-36^{\circ} \mathrm{C}$, summer fuel to $-22{ }^{\circ} \mathrm{C}$, pour point to $-40{ }^{\circ} \mathrm{C}$ for winter fuel to $-47^{\circ} \mathrm{C}$

\begin{abstract}
Density at $20^{\circ} \mathrm{C}, \mathrm{g} / \mathrm{sm}^{3}$
Viscosity at $20^{\circ} \mathrm{C}, \mathrm{mm}^{2} / \mathrm{s}$
\end{abstract}

Molecular weight, $\mathrm{g} / \mathrm{mol}$

$$
0.843
$$

162.803
0.803

3.254

158.772
0.807

4.010

165.412 varies from $16.00 \%$ wt. to $25.85 \%$ wt. The average content of n-paraffins in the diesel fuel samples comprises $19.13 \%$ wt. The content of i-paraffins in the diesel fuel samples varies in the range from $12.33 \%$ wt. to $21.41 \%$ wt. The average content of i-paraffins in the diesel fuels samples is $18.98 \%$ wt. In work [46] by gas-liquid chromatography on a Kristallyuks $4000 \mathrm{M}$ gas chromatograph using a fused silica capillary column, the composition of 9 diesel fuel samples was determined: the content of n-paraffins varies within the range from $9.10 \%$ wt. to $14.70 \%$ wt., the average content of n-paraffins is $11.98 \%$ wt.

According to most standards, the maximum CFPP of diesel fuel grades for cold climates should be between $-15{ }^{\circ} \mathrm{C}$ and $-45^{\circ} \mathrm{C}$, while the CFPP of straight-run diesel is usually not lower than $-10{ }^{\circ} \mathrm{C}$ and $-12{ }^{\circ} \mathrm{C}$.

Three types of diesel fuel cold flow improvers were used in the study. The improvers under the study are commercially available fuel additives, which are used worldwide. The additives were assigned the letter ciphers. The coding of the additives, as well as the information from the producer on their use are presented in Table 1.

\subsection{Methods for determination of physico-chemical, low-temperature properties and operational characteristics of the diesel fuel samples}

The studied samples of straight-run diesel fuel were characterized as follows:

- The sulfur content was determined using the X-ray fluorescence energy dispersive analyzer "SPECTROSCAN S", according to the ASTM D4294-16 "Standard Test Method for Sulfur in Petroleum and Petroleum Products by Energy Dispersive X-ray Fluorescence Spectrometry" [47].

- The density at the temperature of $15{ }^{\circ} \mathrm{C}$ and $20{ }^{\circ} \mathrm{C}$ was determined using the Stabinger SVM 3000 Anton Paar viscometer according to the ISO 3675:1998
"Crude petroleum and liquid petroleum products Laboratory determination of density - Hydrometer method" [48].

- The viscosity at $20{ }^{\circ} \mathrm{C}$ was determined using the Stabinger SVM 3000 Anton Paar, according to the ISO 3104: 1994 "Petroleum products. Transparent and opaque liquids. Determination of kinematic viscosity and calculation of dynamic viscosity" [49].

- The Cetane Index $\left(C I_{\text {ISO }}\right)$ was determined according to the ISO 4264:2018 "Petroleum products - Calculation of cetane index of middle-distillate fuels by the four variable equation" [50-52].

- The Cloud Point $\left(T_{\mathrm{cp}}\right)$ was determined according to the ASTM D2500-05 "Standard Test Method for Cloud Point of Petroleum Products" [53].

- The CFPP was determined according to the ASTM D6371-17a "Standard Test Method for Cold Filter Plugging Point of Diesel and Heating Fuels" [54].

- The Pour Point $\left(T_{\mathrm{pp}}\right)$ was determined according to the ASTM D97-17b "Standard Test Method for Pour Point of Petroleum Products" [55].

\subsection{Methods for determining the composition of the diesel fuel samples}

Fractional composition of the straight-run diesel fuel samples was determined according to the ISO 3405: 011 "Petroleum products - Determination of distillation characteristics at atmospheric pressure" [56].

Structure-group composition of the diesel fuel samples was calculated using the n-d-M method according to the ASTM D3238-17a "Standard Test Method for Calculation of Carbon Distribution and Structural Group Analysis of Petroleum Oils by the n-d-M Method" [57]. To calculate the structural-group composition, according to this method, the diesel fuel samples were characterized as follows: 
Table 2. Mixtures of diesel fuel with cold flow improvers.

\begin{tabular}{|c|c|c|c|c|c|c|}
\hline \multirow[t]{2}{*}{ Additive } & \multicolumn{2}{|c|}{$\begin{array}{l}\text { Addition of the improver in the } \\
\text { amount of half as much as the } \\
\text { amount recommended by the } \\
\text { producer - half concentration }(0.5)\end{array}$} & \multicolumn{2}{|c|}{$\begin{array}{l}\text { Addition of the improver in the } \\
\text { amount recommended by the } \\
\text { producer - singular concentration } \\
\text { (1) }\end{array}$} & \multicolumn{2}{|c|}{$\begin{array}{l}\text { Addition of the improver in the } \\
\text { amount of twice as much as the } \\
\text { amount recommended by the } \\
\text { producer - double concentration (2) }\end{array}$} \\
\hline & $\begin{array}{c}\text { Volume of } \\
\text { additive, } \mathrm{mL}\end{array}$ & $\begin{array}{l}\text { Volume of diesel } \\
\text { fuel, } \mathrm{mL}\end{array}$ & $\begin{array}{c}\text { Volume of } \\
\text { additive, } \mathrm{mL}\end{array}$ & $\begin{array}{l}\text { Volume of diesel } \\
\text { fuel, } \mathrm{mL}\end{array}$ & $\begin{array}{c}\text { Volume of } \\
\text { additive, } \mathrm{mL}\end{array}$ & $\begin{array}{l}\text { Volume of diesel } \\
\text { fuel, } \mathrm{mL}\end{array}$ \\
\hline A & 0.050 & 100 & & 10 & & 10 \\
\hline B & 0.115 & 100 & 0.230 & 100 & 0.460 & 100 \\
\hline $\mathrm{C}$ & 0.150 & 100 & 0.300 & 100 & 0.600 & 100 \\
\hline
\end{tabular}

- The sulfur content was determined using the X-ray fluorescence energy dispersive analyzer "SPECTROSCAN S" according to [47].

- The density at the temperature of $20{ }^{\circ} \mathrm{C}$ was determined using the Stabinger SVM 3000 Anton Paar viscometer according to [48].

- The refractive index was determined using refractometer according to the ASTM D1218-12 "Standard Test Method for Refractive Index and Refractive Dispersion of Hydrocarbon Liquids" [58].

- The molecular weight was determined by the method of cryoscopy according to the ASTM D2224-78 "Method of Test for Mean Molecular Weight of Mineral Insulating Oils by the Cryoscopic Method" [59].

To determine the group composition of the straight-run diesel fuel samples, the aniline method was used. Determination of the group hydrocarbon composition of the diesel fuel samples included the following steps:

- Distillation of the sample into 50-degree fractions $\left(150-200{ }^{\circ} \mathrm{C}, 200-250{ }^{\circ} \mathrm{C}, 250-300{ }^{\circ} \mathrm{C}\right)$.

- Determination of the aniline point of each 50-degree fraction according to the ASTM D611-12(2016) "Standard Test Methods for Aniline Point and Mixed Aniline Point of Petroleum Products and Hydrocarbon Solvents" [60].

- Removal of aromatic hydrocarbons by adsorption on silica gel.

- Determination of the aniline point for the de-aromatized fractions according to [60].

- Calculation of the content of aromatic hydrocarbons, naphthenes and paraffins.

The content of n-paraffins in the straight-run diesel fuel samples was determined by the gas-liquid chromatography method using the Chromatec-Crystal 2000 chromatograph with quartz capillary column $30 \mathrm{~m} \times 0.25 \mathrm{~mm}$, stationary phase - SE-54, carrier gas - helium.

\subsection{Preparation of the mixtures of straight-run diesel fuel with cold flow improvers}

To study the effect of diesel fuel composition on the effectiveness of cold flow improvers, the mixtures of straightrun diesel fuel with additives were prepared according to the producer's recommendations, as well as the mixtures with half and double concentrations of the additives (Tab. 2).

The mixtures were characterized as follows: the cloud point was determined according to [53]; the CFPP was determined according to [54]; the pour point was determined according to [55].

\section{Results and discussion}

\subsection{Characterization of the diesel fuel samples}

The detailed results of the determination of physico-chemical, low-temperature properties, operational characteristics and compositions of the studied diesel fuel samples are presented in Appendix.

The most important characteristics compositions of the studied diesel fuel samples, which are used for the further analysis, are presented in Table 3.

The main standard regulating the quality of diesel fuels produced in the Russian Federation is the USS 305-2013 "Diesel fuel. Specifications" [61], developed on the basis of the EN 590 "Automotive fuels - Diesel - Requirements and test methods" [62]. This standard establishes requirements for diesel fuel in terms of the composition, physicochemical, low-temperature properties and performance characteristics, and determines the production of four types of fuel: summer, off-season, winter and arctic. Specifications [61] are presented in Table 4.

From the results given in Table A.1, it is clear that all samples of diesel fuel meet the requirements of [61] by the cetane index (Tab. 4); by the viscosity at $20{ }^{\circ} \mathrm{C}$ all samples meet requirements for winter grade; by the density at $15^{\circ} \mathrm{C}$ all samples correspond to the winter grade; samples No. 2, 4, 5 meet the requirements of [61] by the sulfur content.

From the results given in Table A.2, it can be seen that none of the tested diesel fuel samples meets the requirements for the CFPP of the winter grade (Tab. 4) [61]. These results allow concluding that the use of the tested diesel fuel in winter conditions is possible only in the case of the use of cold flow improvers.

From the results given in Table A.3 it can be seen that $95 \%$ vol. fraction of all the studied diesel fuel samples boils at the temperature not higher than $360{ }^{\circ} \mathrm{C}$, which satisfies the requirements for all types of fuel according to [61]. By 
Table 3. Compositions of the studied diesel fuel samples.

\begin{tabular}{lccccccc}
\hline Diesel fuel sample & \multicolumn{3}{c}{$T,{ }^{\circ} \mathrm{C}$} \\
\cline { 2 - 7 } & \multicolumn{2}{l}{$V, \%$ vol. } & \multicolumn{3}{c}{ Content, $\%$ wt. } & Number of aromatic rings \\
\cline { 2 - 7 } & 50 & 90 & Aromatics & Naphthenes & Paraffins & N-paraffins & $K_{\text {ar }}$ \\
\hline 1 & 248 & 338 & 23.9 & 30.1 & 46.0 & 20.77 & 0.225 \\
2 & 262 & 332 & 23.5 & 29.6 & 46.9 & 19.08 & 0.285 \\
3 & 271 & 359 & 22.3 & 33.5 & 44.2 & 19.61 & 0.317 \\
4 & 247 & 330 & 22.6 & 31.1 & 46.3 & 22.05 & 0.330 \\
5 & 251 & 312 & 21.7 & 34.7 & 43.7 & 19.88 & 0.378 \\
\hline
\end{tabular}

Table 4. Specifications for diesel fuels according to [61].

\begin{tabular}{|c|c|c|c|c|c|c|}
\hline \multirow[t]{2}{*}{ No. } & \multirow[t]{2}{*}{ Characteristic } & \multirow[t]{2}{*}{ Unit } & \multicolumn{4}{|c|}{ Value for the grade } \\
\hline & & & Summer & Off-season & Winter & Arctic \\
\hline 1 & Cetane number, minimum & Points & \multicolumn{4}{|c|}{45} \\
\hline 2 & Fractional composition: & & & & & \\
\hline 2.1 & Boiling point of $50 \%$ vol. fraction, maximum & ${ }^{\circ} \mathrm{C}$ & \multicolumn{3}{|c|}{280} & 255 \\
\hline 2.2 & Boiling point of $90 \%$ vol. fraction, maximum & ${ }^{\circ} \mathrm{C}$ & \multicolumn{4}{|c|}{360} \\
\hline 3 & Cinematic viscosity at $20^{\circ} \mathrm{C}$ & $\mathrm{mm}^{2} / \mathrm{s}$ & \multicolumn{2}{|r|}{$3.0 / 6.0$} & $1.8 / 5.0$ & $1.5 / 4.0$ \\
\hline 4 & Sulfur content, maximum & ppm & \multicolumn{4}{|c|}{2000} \\
\hline 5 & Density at $15^{\circ} \mathrm{C}$, maximum & $\mathrm{kg} / \mathrm{m}^{3}$ & \multicolumn{2}{|r|}{863.4} & 843.4 & 833.5 \\
\hline 6 & CFPP, maximum & ${ }^{\circ} \mathrm{C}$ & -5 & -15 & $-25 /-35$ & -45 \\
\hline
\end{tabular}

boiling point of $50 \%$ vol. fraction, all samples correspond to the winter grade [61] (Tab. 4).

Characteristics of the diesel fuel samples, required for the determination of structural-group composition using the n-d-M method, are presented in Table A.4. Calculated structural-group composition of the diesel fuel samples is presented in Tables A.5 and A.6. According to the obtained results, carbon is the most abundant in alkyl chains for all samples, except for sample No. 2. For sample No. 2 carbon is mostly presented in ringed structures, which are predominantly naphthenic rings. The smallest amount of carbon is contained in the aromatic rings for all samples. Sample No. 3 is characterized by the highest average number of rings, and the lowest number of rings is observed for sample No. 1. At the same time, the prevalence of the number of naphthenic rings over the aromatic ones is typical of all samples.

The aniline points of 50-degree fractions of the diesel fuel samples were presented in Table A.7. As it is known, the value of the aniline point directly depends on the hydrocarbons constituting the mixture. The value of the aniline point increases in the series: aromatic hydrocarbons - naphthenes - paraffins. The aniline point increases with the increasing molecular weight within hydrocarbon family. As it can be seen from the obtained results, for all the studied diesel fuel samples, the greatest depression of the maximum aniline point (change in the aniline point during dearomatization) is observed for the fraction boiling in the range of $250-300{ }^{\circ} \mathrm{C}$. This indicates the highest content of aromatic hydrocarbons in this fraction. The highest values of the maximum aniline point depression for diesel fuel sample No. 1 indicate the highest content of aromatic hydrocarbons in this sample.

The aniline coefficients required for calculation and calculated group composition of the 50-degree fractions are presented in Table A.8.

Group composition of the diesel fuel samples is presented in Table A.9. According to the obtained results, sample No. 1 contains the greatest amount of aromatic hydrocarbons, sample No. 2 contains the largest number of paraffins, sample No. 5 contains the largest amount of naphthenes. At the same time, for all samples the highest content of paraffins, the lowest content of aromatic hydrocarbons are observed, naphthenes occupy an intermediate position.

The content of n-paraffins and isoparaffins in the diesel fuel samples is presented in Table A.10. As can be seen from the obtained results, sample No. 4 contains the highest amount of n-paraffins, sample No. 2 contains the smallest amount of n-paraffins. The content of heavy n-paraffins $\left(\mathrm{C}_{16+}, \mathrm{C}_{20+}\right)$ is the greatest in sample No. 3 , which explains the fact that this sample has the worst low-temperature properties.

\subsection{Selection of the most effective cold flow improver for the diesel fuel samples of different composition}

To establish the most effective cold flow improver, the CFPP of the mixtures of straight-run diesel fuel with various additives in the concentration recommended by the 
Table 5. CFPP of the diesel fuel and the mixtures of the diesel fuel with the additives.

\begin{tabular}{|c|c|c|c|}
\hline Mixture & $\begin{array}{l}\text { CFPP of the } \\
\text { diesel } \\
\text { fuel, }{ }^{\circ} \mathrm{C}\end{array}$ & $\begin{array}{c}\text { CFPP of } \\
\text { mixture of the } \\
\text { diesel fuel with } \\
\text { additive, }{ }^{\circ} \mathrm{C}\end{array}$ & $\begin{array}{c}\text { CFPP } \\
\text { depression, } \\
{ }^{\circ} \mathrm{C}\end{array}$ \\
\hline $1 \mathrm{~A}_{1}$ & -21 & -32 & 11 \\
\hline $2 \mathrm{~A}_{1}$ & -22 & -30 & 8 \\
\hline $3 \mathrm{~A}_{1}$ & -4 & -11 & 7 \\
\hline $4 \mathrm{~A}_{1}$ & -24 & -31 & 7 \\
\hline $5 \mathrm{~A}_{1}$ & -17 & -28 & 11 \\
\hline \multicolumn{3}{|c|}{ Average depression of $\mathrm{CFPP},{ }^{\circ} \mathrm{C}$} & 8.8 \\
\hline$\overline{1 B_{1}}$ & -21 & -29 & 8 \\
\hline $2 \mathrm{~B}_{1}$ & -22 & -31 & 9 \\
\hline $3 \mathrm{~B}_{1}$ & -4 & -8 & 4 \\
\hline $4 \mathrm{~B}_{1}$ & -24 & -33 & 9 \\
\hline $5 \mathrm{~B}_{1}$ & -17 & -24 & 7 \\
\hline \multicolumn{3}{|c|}{ Average depression of $\mathrm{CFPP},{ }^{\circ} \mathrm{C}$} & 7.4 \\
\hline $1 \mathrm{C}_{1}$ & -21 & -32 & 11 \\
\hline $2 \mathrm{C}_{1}$ & -22 & -30 & 8 \\
\hline $3 \mathrm{C}_{1}$ & -4 & -17 & 13 \\
\hline $4 \mathrm{C}_{1}$ & -24 & -26 & 2 \\
\hline $5 \mathrm{C}_{1}$ & -17 & -28 & 11 \\
\hline \multicolumn{3}{|c|}{ Average depression of $\mathrm{CFPP},{ }^{\circ} \mathrm{C}$} & 9.0 \\
\hline
\end{tabular}

producer were determined. The differences between the CFPP of the pure fuel samples and the CFPP of the fuel samples mixed with the additives were also calculated. Analysis was carried out on the basis of the CFPP, since only this characteristic from all the low-temperature properties of diesel fuel is regulated by the requirements [61]. The results are presented in Table 5 .

According to the data from Table 5, the additive $\mathrm{B}$ on the average ensures the smallest average depression of the $\mathrm{CFPP}$, on the average the greatest depression of the CFPP is observed in case of using the additive C. Thus, among the studied hydrocarbon compositions of diesel fuel, the most effective additive is the additive $\mathrm{C}$. The most effective additive was selected to increase the visibility of the results at the next stages of the study.

\subsection{The influence of concentration of cold flow improvers on their effectiveness}

To assess the effect of concentration of cold flow improvers on their effectiveness, the mixtures of the diesel fuel (samples No. 3 and No. 4) and the three different additives were prepared with three different concentrations of the additive. Samples No. 3 and No. 4 were chosen for testing, since they have the worst and the best low-temperature properties among the available samples, respectively. Low-temperature properties of the prepared mixtures were determined. Dependencies of the CFPP of diesel fuel sample No. 3 on the additive concentration are presented in Figure 1.

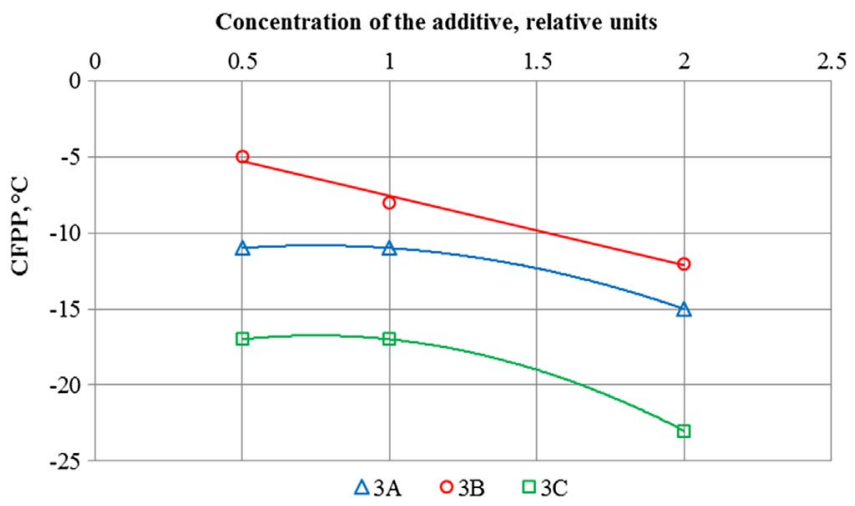

Fig. 1. Dependency of the CFPP of diesel fuel (sample No. 3) on the additive concentration. 1 - singular concentration of the additive; 0.5 - half concentration of the additive; 2 - double concentration of the additive, according to Table 2.

As it can be seen from Figure 1, a linear dependence of the CFPP on the additive B concentration is observed. An increase in the concentrations of the additives $\mathrm{A}$ and $\mathrm{C}$ in comparison to the concentration, recommended by the producer (double concentration of the additive), results in the higher CFPP depression. In case of using the additive A, single concentration provides decreasing of the CFPP by $7{ }^{\circ} \mathrm{C}$, double concentration provides decreasing of the $\mathrm{CFPP}$ by $9{ }^{\circ} \mathrm{C}$. In case of using the additive $\mathrm{C}$, single concentration provides decreasing of the CFPP by $13^{\circ} \mathrm{C}$, double concentration provides decreasing of the CFPP by $19{ }^{\circ} \mathrm{C}$. Using half of additive concentration, recommended by the producer does not reduce the effectiveness of additive (the CFPP of the sample is decreased by $7{ }^{\circ} \mathrm{C}$ and $13{ }^{\circ} \mathrm{C}$ for the additive $\mathrm{A}$ and the additive $\mathrm{C}$ respectively). The results presented in Figure 1 indicate that the most effective additive for diesel fuel sample No. 3 is the additive C.

Dependencies of the CFPP of diesel fuel sample No. 4 on the additive concentration are presented in Figure 2.

From the graph shown in Figure 2, it is clear that the decrease or increase in the concentration of the additive $\mathrm{B}$ does not influence the effectiveness of the additive in terms of the CFPP of diesel sample No. 4 (when using half, single and double concentration of the additive, CFPP is decreased by $9{ }^{\circ} \mathrm{C}$ ). For the additives $\mathrm{A}$ and $\mathrm{C}$, an increase in the concentration of the additive as compared to that recommended by the producer leads to a further decrease in the CFPP of the fuel (the additive A: single concentration provides decreasing of the CFPP by $7{ }^{\circ} \mathrm{C}$, double concentration provides decreasing of the CFPP by $10{ }^{\circ} \mathrm{C}$; the additive C: single concentration provides decreasing of the CFPP by $2{ }^{\circ} \mathrm{C}$, double concentration provides decreasing of the CFPP by $10^{\circ} \mathrm{C}$ ). However, the decrease in the additive $\mathrm{C}$ concentration compared to that recommended by the producer does not reduce the effectiveness of the additive action (in both cases the CFPP of the sample decreases by $2{ }^{\circ} \mathrm{C}$ ); as for the additive $\mathrm{A}$, the decrease in the concentration almost does not reduce the effectiveness of the additive (half concentration provides decreasing of the CFPP by $6{ }^{\circ} \mathrm{C}$, single concentration provides decreasing the CFPP by $7{ }^{\circ} \mathrm{C}$ ). The results presented in Figure 2, 


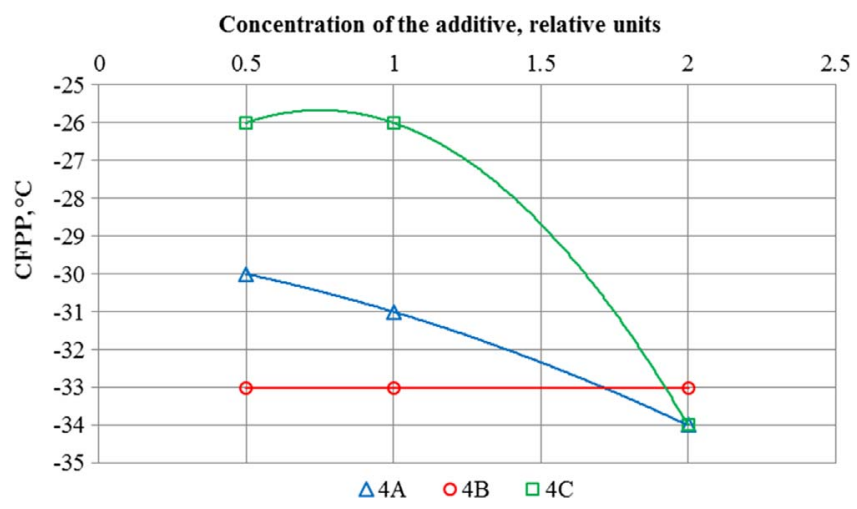

Fig. 2. Dependency of the CFPP of diesel fuel (sample No. 4) on the additive concentration. 1 - singular concentration of the additive; 0.5 - half concentration of the additive; 2 - double concentration of the additive, according to Table 2 .

indicate that when comparison is done in the concentrations recommended by the producer, the most effective additive for diesel sample No. 4 is the additive B. However, it should be noted that, in fact, the efficiency limit has been reached for the additive $\mathrm{B}$, while a significant decrease of the CFPP is observed when the additive $\mathrm{C}$ is added in double concentration, which makes the additive $\mathrm{C}$ more promising for obtaining low-freezing diesel fuels.

The established dependences clearly show that concentration recommended by the producer for diesel fuel is not optimal, since the use of an additive in concentration of half the recommended allows achieving similar results. This effect is caused by the influence of diesel fuel composition on the effectiveness of cold flow improvers.

\subsection{The effect of diesel fuel composition on the effectiveness of cold flow improvers}

To study the effect of diesel fuel composition on the effectiveness of cold flow improvers, the cloud point, the CFPP, and the pour point of the diesel fuels mixed with the additive $\mathrm{C}$ were determined (the additive $\mathrm{C}$ was selected for this study as the most effective). The amount of additive was the amount recommended by the producer (Tab. 1). Depression of low-temperature characteristics of the diesel fuel was calculated. The results are presented in Table 6 .

Weak dispersing effect of the additive $\mathrm{C}$ on all the studied diesel fuel samples, except for sample No. 2, is observed. The additives can be attributed to the depressant type. The best effect on both the CFPP and the pour point improvement is observed for samples No. 3,5 and the additive C (Tab. 6).

According to the data presented in Table 6 and group composition of the diesel fuel samples (Tabs. A.9 and A.10), with an increase in the content of n-paraffins in the diesel fuel, the effectiveness of the additive on the CFPP decreases. From the data on the fractional composition of the diesel fuel samples, presented in Table 3, it is clear that with an increase in the boiling point of $50 \%$ vol. and $90 \%$ vol. fraction the effectiveness of the additive in relation to the pour point of the samples increases.

\subsection{The mechanism of the additives action on the cold flow properties of diesel fuels of various compositions}

According to the obtained results, the following can be concluded: an increase in the content of n-paraffins in diesel fuel, in general, adversely influences the effectiveness of the depressant, while an increase in the proportion of heavy n-paraffins influences the effectiveness of the additive positively.

The first conclusion is explained by the mechanism of depressant additives action. N-paraffins are characterized by the best susceptibility of the depressant additives, since the depressants are designed to interact with the nascent $\mathrm{n}$-paraffin crystals. However, if the amount of n-paraffins in fuel is too high (for the studied straight-run diesel fuel samples, the n-paraffin content is high, an average of $20.28 \%$ wt.) the effectiveness of the depressant decreases. To overcome this effect, a significant increase in the additive concentration is required (for sample No. 3 mixed with the additive $\mathrm{C}$, the use of single concentration instead of half concentration does not further decrease the CFPP, but increasing the concentration of the additive 4 times, relative to half, allows further decreasing the CFPP by $\left.6{ }^{\circ} \mathrm{C}\right)$. Feasibility of a such significant increase in the concentration of the additives in each case should be evaluated, first of all, from the economic point of view. Thus, it is necessary to establish the optimal n-paraffin content in diesel fuel, at which the maximum effectiveness of the depressant is achieved.

The revealed positive effect of an increase in the content of heavy n-paraffins on the effectiveness of the additive, is also explained by the mechanism of the depressants action. Heavy n-paraffins easily form crystal nuclei, which are necessary for adsorption of the depressant on their surface $[29,44]$.

The influence of the content of aromatic hydrocarbons in diesel fuel can be described as follows: with a decrease in the content of aromatic hydrocarbons, the additive more effectively influences the pour point, however, with an increase in the average number of aromatic rings in the molecule $\left(C_{\mathrm{ar}}\right)$, the effectiveness of the additive increases. It follows from the above: an increase in the proportion of aromatic hydrocarbons in diesel fuel, in general, adversely influences the effectiveness of the additive, but the presence of heavy polycyclic hydrocarbons increases the effectiveness of the additive.

The established effect can be explained as follows: it is known that aromatic hydrocarbons are characterized by high susceptibility to the depressant additives. Depending on the structure of the aromatic hydrocarbon molecule, its susceptibility to the depressants may be higher than that of paraffinic hydrocarbons. A high amount of aromatic hydrocarbons in diesel fuel leads to the fact that the depressants are adsorbed on aromatic molecules, without stopping the growth of the paraffin crystals, and the effectiveness of the cold flow improver decreases. With an increase in the number of rings, the susceptibility of aromatic hydrocarbons to the depressants decreases. The presence of heavy polycyclic aromatic hydrocarbons increases the effectiveness of the additive [63]. 
Table 6. Low-temperature properties of the pure diesel fuel and the diesel fuel mixed with the additive.

\begin{tabular}{lccc}
\hline Mixture & $T_{\mathrm{cp}}$ of pure diesel fuel, ${ }^{\circ} \mathrm{C}$ & $T_{\mathrm{cp}}$ of fuel mixed with additive, ${ }^{\circ} \mathrm{C}$ & Depression of $T_{\mathrm{cp}},{ }^{\circ} \mathrm{C}$ \\
\hline $1 \mathrm{C}_{1}$ & -15 & -16 & 1 \\
$2 \mathrm{C}_{1}$ & -12 & -17 & 5 \\
$3 \mathrm{C}_{1}$ & -3 & -4 & 1 \\
$4 \mathrm{C}_{1}$ & -12 & -12 & 0 \\
$5 \mathrm{C}_{1}$ & -13 & -15 & 2 \\
\hline
\end{tabular}

\begin{tabular}{lccc}
\hline Mixture & CFPP of pure diesel fuel, ${ }^{\circ} \mathrm{C}$ & CFPP of fuel mixed with additive, ${ }^{\circ} \mathrm{C}$ & Depression of CFPP, ${ }^{\circ} \mathrm{C}$ \\
\hline $1 \mathrm{C}_{1}$ & -21 & -32 & 11 \\
$2 \mathrm{C}_{1}$ & -22 & -30 & 8 \\
$3 \mathrm{C}_{1}$ & -4 & -17 & 13 \\
$4 \mathrm{C}_{1}$ & -24 & -26 & 11 \\
$5 \mathrm{C}_{1}$ & -17 & -28 & 0 \\
\hline Mixture & $T_{\mathrm{pp}}$ of pure diesel fuel, ${ }^{\circ} \mathrm{C}$ & $T_{\mathrm{pp}}$ of fuel mixed with additive, ${ }^{\circ} \mathrm{C}$ & Depression of $T_{\mathrm{pp}},{ }^{\circ} \mathrm{C}$ \\
\hline $1 \mathrm{C}_{1}$ & -35 & -35 & 7 \\
$2 \mathrm{C}_{1}$ & -32 & -39 & 10 \\
$3 \mathrm{C}_{1}$ & -18 & -28 & 5 \\
$4 \mathrm{C}_{1}$ & -45 & -50 & 10 \\
$5 \mathrm{C}_{1}$ & -29 & -39 & 0 \\
\hline
\end{tabular}

The established dependences explain the best effect of the additive $\mathrm{C}$ in relation to diesel fuel samples No. 3 and No. 5 , as well as the worst effect of the additive $\mathrm{C}$ in relation to diesel fuel sample No. 4. These samples are characterized by the lowest content of n-paraffin and aromatic hydrocarbons, sample No. 3 is characterized by the highest content of heavy n-paraffin hydrocarbons, and sample No. 5 is characterized by the highest content of polycyclic aromatic hydrocarbons. Sample No. 4 is characterized by the highest content of n-paraffins, comparably low content of aromatic hydrocarbons and the lightest fractional composition.

To analyze isoparaffins influence, it is known that isoparaffins are characterized by low crystallization temperatures. Due to this fact, the more the content of isoparaffins in the diesel fuel, the better the low-temperature properties of the fuel. Regarding the effect of cold flow improvers, the content of isoparaffins does not have a significant influence on the effect of depressants, since depressants begin to act only after the appearance of the first crystals, in the case of isoparaffins this occurs only at sufficiently low temperatures. At the same time, isoparaffin molecules are not as polar as aromatic ones, and cannot drag the effect of the additive on themselves.

Thus, when selecting a cold flow improver for diesel fuel and determining its optimal concentration, the following should be considered:

- Optimal n-paraffin content in diesel fuel at which the effect of the depressant is most effective.

- High content of heavy n-paraffins in diesel fuel (determined by the boiling temperature of $90 \%$ vol. fraction) increases the effectiveness of the cold flow improvers.
- High content of aromatic hydrocarbons in diesel fuel decreases the effectiveness of the cold flow improvers, while increasing polycyclic aromatic hydrocarbons content increases the effectiveness of the additives.

\section{Conclusion}

1. It was established that the use of the considered straight-run fuels in winter conditions is possible only in case of the cold flow improvers use.

2. The effect of three depressing-dispersing additives on the low-temperature properties of the straight-run diesel fuel was experimentally studied. The investigated additives contain in their composition ethylenevinyl-acetate copolymers and some of paraffin and aromatic hydrocarbons. It was found that the most effective additive for the studied compositions of diesel fuel is the additive $\mathrm{C}$. The most effective additive was selected to increase the visibility of the results at the next stages of the study.

3. It was established that, for the additives $\mathrm{A}$ and $\mathrm{C}$, a decrease in concentration twice (compared to the producer's recommended value) does not influence the effectiveness of the additive, but an increase in the concentration twice (as compared to the producer's recommended value) increases the effectiveness of the additive. In case of the additive $\mathrm{B}$, increasing the concentration improves the effectiveness of the additive.

4. The qualitative influence of fractional, group and structural-group composition of the straight-run 
diesel fuel on the effectiveness of the depressing-dispersing additives was studied. It was established that an increase in the proportion of n-paraffins in diesel fuel, in general, adversely influences the effectiveness of the additive, while an increase in the proportion of heavy n-paraffins influences the effectiveness of the additive positively. This conclusion is explained by the mechanism of depressing additives action.

5. It was established that an increase in the proportion of aromatic hydrocarbons in diesel fuel, in general, adversely influences the effectiveness of the additive, but the presence of heavy polycyclic hydrocarbons increases the effectiveness of the additive.

6. It was shown that when selecting a cold flow improver for diesel fuel and determining its optimal concentration, it is necessary to take into account the optimal content of n-paraffins in diesel fuel, at which the depressing additive is the most effective.

Based on the obtained dependencies, the mechanism of interaction between the functional groups of additives and the diesel fraction components will be further developed, as well as the method of selection of cold flow improvers and their optimal concentration, taking into account the composition of diesel fuel.

Acknowledgments. The research is supported by the Tomsk Polytechnic University within the framework of Tomsk Polytechnic University Competitiveness Enhancement Program and Russian State Project "Science" No. FSWW-2020-0011.

\section{References}

1 Grudanova A.I., Gulyaeva L.A., Krasilnikova L.A., Shmelkova O.I., Boldushevskii R.E. (2017) Jet fuel and arctic diesel fuel production by isodewaxing of waxy middle distillate fractions, Fuel 193, 485-487.

2 Hönig V., Linhart Z., Orsák M. (2016) Effect of gasoline contamination on the quality of arctic diesel fuel, Agron. Res. 14, 2, 400-406.

3 Belinskaya N.S., Ivanchina E.D., Dolganov I.M., Belozertseva N.E., Afanaseva D.A. (2020) Computer modelling system of the industrial diesel fuel catalytic dewaxing process, Chem. Eng. Technol. 44, 1, 31-37. https://doi. org $/ 10.1002 /$ ceat.201900516.

4 Kirgina M.V., Bogdanov I.A., Altynov A.A., Krinitsyn N.S. (2019) Feasibility studies of jet fuels using as a lowtemperature additiveto straight-run diesel fuels, Pet. Coal 61, 1, 120-127.

5 Goberdhan D., Hunt R. (2015) Exploiting the understanding of diesel fuel solvency to improve low temperature properties as exemplified for the Korean market, in: International Powertrains, Fuels and Lubricants Meeting, SAE Technical Papers.

6 Savost'yanov A.P., Narochnyi G.B., Yakovenko R.E., Saliev A.N., Sulima S.I., Zubkov I.N., Nekroenko S.V., Mitchenko S.A. (2017) Synthesis of low-pour-point diesel fuel in the presence of a composite cobalt-containing catalyst, Pet. Chem. 57, 12, 1186-1189.

7 Liu B., Li L., Ye X. (2017) Cause analysis of unqualified cold filter plugging point of diesel fuel and measures, Pet. Process. Petrochem. 48, 8, 39-42.
8 Murphy F., Devlin G., Mcdonnell K. (2013) The evaluation of flash point and cold filter plugging point with blends of diesel and Cyn-diesel pyrolysis fuel for automotive engines, Open Fuels Energy Sci. J. 6, 1, 1-8.

9 Belinskaya N.S., Mauzhigunova E.N., Afanaseva D.A., Vymyatnin E.K. (2020) Identification of regularities of vacuum gas oil hydrocracking process, Pet. Coal 62, 2, 390-395.

10 Zinnatullina G.M., Baulin O.A., Spashenko A.Yu., Alipov D.E., Shaikhutdinova R.T. (2018) Improvement of diesel fuel low-temperature properties, SOCAR Proc. 2, 77-81.

11 Saeedi Dehaghani A.H., Rahimi R. (2018) An experimental study of diesel fuel cloud and pour point reduction using different additives, Petroleum 5, 4, 413-416.

12 Kirgina M., Bogdanov I., Belinskaya N., Altynov A., Morozova Y. (2020) Expansion of the feedstock base for the production of diesel fuel by involving the heavy fractions and cold flow improvers, Oil Gas Sci. Technol. - Rev. IFP Energies nouvelles $\mathbf{7 5}, 31$.

13 Zhang H.K., Liu H.Y., Wang S.J. (2008) Synthesis of a new low temperature flow improver for diesel fuel and its CFPP reducing properties, Acta Pet. Sin. 24, 1, 85-89.

14 Agaev S.G., Yakovlev N.S., Gul'tyaev S.V. (2007) Improvement of low-temperature properties of diesel fuels, Russ. J. Appl. Chem. 80, 3, 486-491.

15 Xu G., Xue Y., Zhao Z., Lian X., Lin H., Han S. (2018) Influence of poly (methacrylate-co-maleic anhydride) pour point depressant with various pendants on low-temperature flowability of diesel fuel, Fuel 216, 898-907.

16 Zhao Z., Yan S., Lian J., Chang W., Xue Y., He Z., Bi D., Han S. (2018) A new kind of nanohybrid poly(tetradecyl methyl-acrylate)-graphene oxide as pour point depressant to evaluate the cold flow properties and exhaust gas emissions of diesel fuels, Fuel 216, 818-825.

17 Zhao Z., Xue Y., Xu G., Zhou J., Lian X., Liu P., Chen D., Han S., Lin H. (2017) Effect of the nano-hybrid pour point depressants on the cold flow properties of diesel fuel, Fuel 193, 65-71.

18 Farazmand S., Ehsani M.R., Shadman M.M., Ahmadi S., Veisi S., Abdi E. (2016) The effects of additives on the reduction of the pour point of diesel fuel and fuel oil, Pet. Sci. Technol. 34, 17-18, 1542-1549.

19 Zhou M., He Y., Chen Y., Yang Y., Lin H., Han S. (2015) Synthesis and evaluation of terpolymers consist of methacrylates with maleic anhydride and methacrylic morpholine and their amine compound as pour point depressants in diesel fuels, Energy Fuels 29, 9, 5618-5624.

20 Feng L.J., Zhang Z.Q., Wang F., Wang T., Yang S. (2013) Performance of AVS diesel fuel pour point depressant, Oilfield Chem. 30, 4, 586-589.

21 Du T., Wang S., Liu H., Zhang Y., Song C. (2011) Study on dialkylfumarate terpolymer lowering cold filter plugging point for diesel fuel, Pet. Sci. Technol. 29, 17, 1753-1764.

22 Du T., Wang S., Liu H., Zhang Y. (2010) Study on dibehenyl fumarate-vinyl acetate copolymer for lowering cold filter plugging point of diesel fuel, China Pet. Process. Petrochem. Technol. 12, 4, 52-56.

23 Maithufi M.N., Joubert D.J., Klumperman B. (2011) Application of gemini surfactants as diesel fuel wax dispersants, Energy Fuels 25, 1, 162-171.

24 Beck A., Bubálik M., Hancsók J. (2009) Development of a novel multifunctional succinic-type detergent-dispersant additive for diesel fuel, Chem. Eng. Trans. 17, 1747-1752. 
25 Lown A., Peereboom L., Miller D.J., Lira C.T. (2012) Cloud point studies for diesel and jet fuel bio-derived fuels, in: 12 AIChE - 2012 Proceedings, Curran Associates, Inc., New York, USA, 48 p.

26 Pistillo W.R., Cerda De Groote C.L. (2005) Cloud point depressant response effects in ultra-low-sulfur diesel fuel, in: Powertrain and Fluid Systems Conference and Exhibition 2005, SAE Technical Papers.

27 Manka J.S., Lindenfelser E.A., Heller F.E. (2001) Using cloud point depressants opportunistically to reduce no.2 diesel fuel cloud point giveaway, in: International Spring Fuels and Lubricants Meeting and Exhibition 2001, SAE Technical Papers.

28 Ziegler K.L., Manka J.S. (2000) The effect of mixing diesel fuels additized with kerosene and cloud point depressants, in: International Fall Fuels and Lubricants Meeting and Exposition 2000, SAE Technical Papers.

29 Ovchinnikova A.V., Boldinov V.A., Esipko E.A., Prozorova I.S. (2005) Effect of n-paraffins on the low-temperature properties of aviation diesel fuel, Chem. Technol. Fuels Oils 41, 6, 462-467.

30 Beck T., Pölczmann G., Eller Z., Hancsók J. (2014) Investigation of the effect of detergent-dispersant additives on the oxidation stability of biodiesel, diesel fuel and their blends, Biomass Bioenergy 66, 328-336.

31 Wang S., Shen J., Reaney M.J.T. (2012) Lubricity-enhancing low-temperature diesel fuel additives, J. Am. Oil Chem. Soc. 89, 3, 513-522.

32 Cheng L., Zhao J., Shen B. (2009) Effect of the compatibility of cold flow improvers on the cold filter plugging point of FCC diesel fuel, Pet. Process. Petrochem. 40, 5, 61-65.

33 Han S., Zeng K., Lin H., Wang P. (2010) Selecting pour depressants for diesel fuels, Chem. Technol. Fuels Oils 46, 5, 309-318.

34 Khidr T.T., Doheim M.M., El-Shamy O.A.A. (2015) Effect of ethoxylate on pour point depressant of fuel, Oil Energy Sour. Part A 37, 15, 1697-1703.

35 Khidr T.T. (2015) The Effect of Commercial Additives as Pour Point Depressants for Fuel, Oils Pet. Sci. Technol. 33, 9, 975-983.

36 Khidr T.T., Doheim M.M., El-Shamy O.A.A. (2015) Pour point depressant of fuel oil using non-ionic surfactants, Pet. Sci. Technol. 33, 17-18, 1619-1626.

37 Kondrasheva N.K., Kondrashev D.A. (2015) Production of low-viscosity marine fuels with improved environmental and low-temperature properties, Pet. Chem. 55, 1, 68-73.

38 Ghosh P., Hoque M., Nandi D. (2015) Homo- and copolymers of decyl methacrylate as performance additives for lube oil, Pet. Sci. Technol. 33, 8, 920-927.

39 Ghosh P., Saha D.K. (2015) Acrylate terpolymers as potential pour point depressant and viscosity modifiers for lube oil, Pet. Sci. Technol. 33, 10, 1126-1132.

40 Singh R.K., Kukrety A., Kumar A., Chouhan A., Saxena R. C., Ray S.S., Jain S.L. (2018) Synthesis, characterization, and performance evaluation of N, N-Dimethylacrylamidealkyl acrylate copolymers as novel multifunctional additives for lube oil, Adv. Polym. Technol. 37, 6, 1695-1702.

41 Ahmed N.S., Nassar A.M., Nasser R.M., Haseeb M.E., AbdelRahman A.A.-H. (2017) Preparation and evaluation of some antioxidant lube oil additives, Pet. Coal 59, 6, 847-855.

42 Upadhyay M., Dey K., Ghosh P. (2016) Biodegradable multifunctional additives for lube oil: Synthesis and characterization, Pet. Sci. Technol. 34, 14, 1255-1262.
43 Du T., Wang S., Liu H., Liu J. (2013) Study on commercial pour point depressants lowering cold filter plugging point for daqing diesel fuels, Pet. Sci. Technol. 31, 10, 1078-1084.

44 Yang H.M., Zhang H.C., Cai X.D. (2014) Susceptibility studies of diesel fuel depressant and diesel composition, Oilfield Chem. 31, 4, 589-593.

45 Chakravarthy R., Acharya C., Savalia A., Naik G.N., Das A.K., Saravanan C., Verma A., Gudasi K.B. (2018) Property prediction of diesel fuel based on the composition analysis data by two-dimensional gas chromatography, Energy Fuels 32, 3, 3760-3774.

46 Ivanova L.V., Koshelev V.N., Burov E.A. (2014) Influence of the hydrocarbon composition of diesel fuels on their performance characteristics, Pet. Chem. 54, 6, 466-472.

47 ASTM D4294-16. (2016) Standard test method for sulfur in petroleum and petroleum products by energy dispersive X-ray fluorescence spectrometry.

48 ISO 3675:1998. (1998) Crude petroleum and liquid petroleum products. Laboratory determination of density. Hydrometer method.

49 ISO 3104:1994. (1994) Petroleum products. Transparent and opaque liquids. Determination of kinematic viscosity and calculation of dynamic viscosity.

50 ISO 4264:2018. (2018) Petroleum products - Calculation of cetane index of middle-distillate fuels by the four variable equation.

51 Altynov A.A., Bogdanov I.A., Kirgina M.V., Sakhnevich B. V. (2016) Determination of operational characteristics of diesel fuel: A study on computational methods, in: Proceedings-2016 11th International Forum on Strategic Technology, IFOST 2016, Institute of Electrical and Electronics Engineers Inc., Novosibirsk, Russia, pp. 615-618.

52 Kirgina M.V., Bogdanov I.A., Altynov A.A., Belinskaya N.S. (2019) Calculation method for prediction of the cetane index of blended diesel fuels, Pet. Coal 61, 1, 110-119.

53 ASTM D2500-05. (2017) Standard Test Method for Cloud Point of Petroleum Products.

54 ASTM D6371-17a. (2017) Standard Test Method for Cold Filter Plugging Point of Diesel and Heating Fuels.

55 ASTM D97-17b. (2017) Standard Test Method for Pour Point of Petroleum Products.

56 ISO 3405:2011. (2011) Petroleum products. Determination of distillation characteristics at atmospheric pressure.

57 ASTM D3238-17a. (2017) Standard Test Method for Calculation of Carbon Distribution and Structural Group Analysis of Petroleum Oils by the $n$-d-M Method.

58 ASTM D1218-12. (2012) Standard Test Method for Refractive Index and Refractive Dispersion of Hydrocarbon Liquids.

59 ASTM D2224-78. (1983) Method of Test for Mean Molecular Weight of Mineral Insulating Oils by the Cryoscopic Method.

60 ASTM D611-12(2016). (2012) Standard Test Methods for Aniline Point and Mixed Aniline Point of Petroleum Products and Hydrocarbon Solvents.

61 USS 305-2013. (2013) Diesel fuel. Specifications.

62 EN 590. (2009) Automotive fuels - Diesel - Requirements and test methods.

63 Veretennikova T.N., Englin B.A., Nikolaeva V.G., Mitusova T.N. (1980) Mechanism of action of pour-point depressants in diesel fuels, Chem. Technol. Fuels Oils. 16, 6, 392-395. 


\section{Appendix}

Table A.1. Physico-chemical properties and operational characteristics of the diesel fuel samples.

\begin{tabular}{lccccc}
\hline Diesel fuel sample & $\begin{array}{c}\text { Sulphur content, } \\
\mathrm{mg} / \mathrm{kg}\end{array}$ & $\begin{array}{c}\text { Density at } 15{ }^{\circ} \mathrm{C}, \\
\mathrm{g} / \mathrm{sm}^{3}\end{array}$ & $\begin{array}{c}\text { Density at } 20{ }^{\circ} \mathrm{C}, \\
\mathrm{g} / \mathrm{sm}^{3}\end{array}$ & $\begin{array}{c}\text { Viscosity } \\
\text { at } 20^{\circ} \mathrm{C}, \mathrm{mm}^{2} / \mathrm{s}\end{array}$ & $\mathrm{CI}_{\text {ISO }}$, points \\
\hline 1 & 2420 & 0.832 & 0.828 & 3.815 & 48.6 \\
2 & 711 & 0.838 & 0.834 & 4.227 & 49.0 \\
3 & 2517 & 0.842 & 0.838 & 4.583 & 48.7 \\
4 & 1700 & 0.831 & 0.828 & 1.960 & 47.2 \\
5 & 1710 & 0.833 & 0.830 & 2.490 & 47.1 \\
\hline
\end{tabular}

Table A.2. Low-temperature properties of the diesel fuel samples.

\begin{tabular}{lccc}
\hline Diesel fuel sample & $T_{\mathrm{cp}},{ }^{\circ} \mathrm{C}$ & $\mathrm{CFPP},{ }^{\circ} \mathrm{C}$ & $T_{\mathrm{pp}},{ }^{\circ} \mathrm{C}$ \\
\hline 1 & -15 & -21 & -35 \\
2 & -12 & -22 & -32 \\
3 & -3 & -4 & -18 \\
4 & -11 & -24 & -45 \\
5 & -13 & -17 & -29 \\
\hline
\end{tabular}

Table A.3. Fractional composition of the diesel fuel samples.

\begin{tabular}{|c|c|c|c|c|c|c|c|c|c|c|c|}
\hline \multirow[t]{3}{*}{ Diesel fuel sample } & \multicolumn{11}{|c|}{$T,{ }^{\circ} \mathrm{C}$} \\
\hline & \multirow[t]{2}{*}{$T_{\mathrm{IBP}}$} & \multicolumn{10}{|c|}{$V, \mathrm{ml}$} \\
\hline & & 10 & 20 & 30 & 40 & 50 & 60 & 70 & 80 & 90 & 95 \\
\hline 1 & 160 & 189 & 200 & 216 & 232 & 248 & 265 & 284 & 304 & 338 & 342 \\
\hline 2 & 149 & 190 & 211 & 229 & 248 & 262 & 276 & 292 & 309 & 332 & 343 \\
\hline 3 & 151 & 183 & 211 & 222 & 254 & 271 & 289 & 310 & 329 & 359 & 360 \\
\hline 4 & 138 & 161 & 179 & 204 & 227 & 247 & 266 & 284 & 306 & 330 & - \\
\hline 5 & 145 & 159 & 190 & 211 & 235 & 251 & 270 & 282 & 297 & 312 & 320 \\
\hline
\end{tabular}

Table A.4. Characteristics of the diesel fuel samples required for calculation of the structural-group composition.

\begin{tabular}{lcccc}
\hline Diesel fuel sample & Sulphur content, \%wt & Density at $20^{\circ} \mathrm{C}, \mathrm{g} / \mathrm{sm}^{3}$ & Refractive index & Molecular weight, $\mathrm{g} / \mathrm{mol}$ \\
\hline 1 & 0.1846 & 0.8275 & 1.4610 & 230.736 \\
2 & 0.0540 & 0.8365 & 1.4649 & 178.545 \\
3 & 0.2476 & 0.8435 & 1.4691 & 210.947 \\
4 & 0.1759 & 0.8384 & 1.4671 & 190.345 \\
5 & 0.2055 & 0.8419 & 1.4698 & 196.046 \\
\hline
\end{tabular}


Table A.5. Carbon distribution in the diesel fuel samples.

\begin{tabular}{lcccr}
\hline Diesel fuel sample & \multicolumn{4}{c}{ Carbon distribution, \% wt. } \\
\cline { 2 - 5 } & $C_{\mathrm{ar}}$ & $C_{\mathrm{n}}$ & $C_{\mathrm{r}}$ & $C_{\mathrm{al}}$ \\
\hline 1 & 8.063 & 25.860 & 33.924 & 66.076 \\
2 & 13.229 & 41.242 & 54.471 & 45.529 \\
3 & 12.453 & 35.684 & 48.137 & 51.863 \\
4 & 14.385 & 35.259 & 49.644 & 50.356 \\
5 & 16.021 & 32.639 & 48.660 & 51.340 \\
\hline
\end{tabular}

$C_{\mathrm{ar}}$ - the mass fraction of carbon in aromatic rings, $\%$ wt.; $C_{\mathrm{n}}$ - the mass fraction of carbon in naphthenic structures, $\%$ wt.; $C_{\mathrm{r}}$ - the mass fraction of carbon in ringed structures, $\%$ wt.; $C_{\mathrm{al}}$ - the mass fraction of carbon in alkyl substituents, \% wt.

Table A.6. The average number of rings in the molecule of diesel fuel samples.

\begin{tabular}{lccr}
\hline Diesel fuel sample & \multicolumn{2}{c}{ Average number of rings in the molecule } \\
\cline { 2 - 4 } & $K_{\mathrm{ar}}$ & $K_{\mathrm{n}}$ & $K_{\text {tot }}$ \\
\hline 1 & 0.225 & 0.736 & 0.961 \\
2 & 0.285 & 0.931 & 1.216 \\
3 & 0.317 & 0.930 & 1.247 \\
4 & 0.330 & 0.839 & 1.169 \\
5 & 0.378 & 0.798 & 1.176 \\
\hline
\end{tabular}

Table A.7. Aniline points of 50-degree fractions of the diesel fuel samples.

\begin{tabular}{lccccc}
\hline $\begin{array}{l}\text { Diesel fuel } \\
\text { sample }\end{array}$ & $\begin{array}{c}\text { Cut boiling } \\
\text { ranges, }{ }^{\circ} \mathrm{C}\end{array}$ & \multicolumn{3}{c}{ Aniline point, ${ }^{\circ} \mathrm{C}$} & $\begin{array}{c}\text { Depression of maximum } \\
\text { aniline point }\end{array}$ \\
\cline { 3 - 5 } 1 & $150-200$ & 57.6 & 68.6 & 78.0 & 11.0 \\
& $200-250$ & 61.8 & 77.4 & 85.8 & 15.6 \\
2 & $250-300$ & 70.0 & 87.4 & 93.0 & 17.4 \\
& $150-200$ & 57.6 & 71.0 & 78.0 & 13.4 \\
& $200-250$ & 62.0 & 76.4 & 85.8 & 14.4 \\
3 & $250-300$ & 70.6 & 86.2 & 93.0 & 15.6 \\
& $150-200$ & 57.4 & 69.4 & 78.0 & 12.0 \\
4 & $200-250$ & 62.4 & 76.2 & 85.8 & 13.8 \\
4 & $250-300$ & 70.4 & 85.4 & 93.0 & 15.0 \\
& $150-200$ & 57.2 & 69.2 & 78.0 & 12.0 \\
5 & $200-250$ & 63.8 & 76.8 & 85.8 & 13.0 \\
5 & $250-300$ & 70.5 & 86.9 & 93.0 & 16.4 \\
& $150-200$ & 57.1 & 68.2 & 78.0 & 11.1 \\
& $200-250$ & 62.8 & 76.4 & 85.8 & 13.6 \\
& $250-300$ & 70.9 & 85.8 & 93.0 & 14.9 \\
\hline
\end{tabular}


Table A.8. Group composition of 50-degree fractions of the diesel fuel samples and the aniline coefficients.

\begin{tabular}{|c|c|c|c|c|c|c|}
\hline \multirow[t]{2}{*}{$\begin{array}{l}\text { Diesel fuel } \\
\text { sample }\end{array}$} & \multirow[t]{2}{*}{$\begin{array}{l}\text { Cut boiling } \\
\text { ranges, }{ }^{\circ} \mathrm{C}\end{array}$} & \multicolumn{2}{|c|}{$\begin{array}{l}\text { Aniline } \\
\text { coefficients }\end{array}$} & \multicolumn{3}{|c|}{ Content of hydrocarbons, $\%$ wt. } \\
\hline & & $K$ & $K_{1}$ & Aromatics & Naphthenes & Paraffins \\
\hline \multirow[t]{3}{*}{1} & $150-200$ & 1.495 & 5 & 16.45 & 39.27 & 44.28 \\
\hline & $200-250$ & 1.624 & & 25.33 & 31.36 & 43.31 \\
\hline & $250-300$ & 1.719 & & 29.91 & 19.63 & 50.46 \\
\hline \multirow[t]{3}{*}{2} & $150-200$ & 1.483 & & 19.87 & 28.04 & 52.08 \\
\hline & $200-250$ & 1.636 & & 23.56 & 35.93 & 40.51 \\
\hline & $250-300$ & 1.744 & & 27.21 & 24.75 & 48.04 \\
\hline \multirow[t]{3}{*}{3} & $150-200$ & 1.490 & & 17.88 & 35.31 & 46.81 \\
\hline & $200-250$ & 1.658 & & 22.88 & 37.02 & 40.10 \\
\hline & $250-300$ & 1.750 & & 26.25 & 28.03 & 45.73 \\
\hline \multirow[t]{3}{*}{4} & $150-200$ & 1.490 & & 17.88 & 36.13 & 45.99 \\
\hline & $200-250$ & 1.650 & & 21.45 & 35.35 & 43.20 \\
\hline & $250-300$ & 1.734 & & 28.44 & 21.83 & 49.74 \\
\hline \multirow[t]{3}{*}{5} & $150-200$ & 1.495 & & 16.59 & 40.87 & 42.54 \\
\hline & $200-250$ & 1.644 & & 22.36 & 36.49 & 41.15 \\
\hline & $250-300$ & 1.751 & & 26.09 & 26.61 & 47.30 \\
\hline
\end{tabular}

Table A.9. Group composition of the diesel fuel samples.

\begin{tabular}{lccc}
\hline Diesel fuel sample & \multicolumn{2}{c}{ Content of hydrocarbons, \% wt. } \\
\cline { 2 - 4 } & Aromatics & Naphthenes & Paraffins \\
\hline 1 & 23.9 & 30.1 & 46.0 \\
2 & 23.5 & 29.6 & 46.9 \\
3 & 22.3 & 33.5 & 44.2 \\
4 & 22.6 & 31.1 & 46.3 \\
5 & 21.7 & 34.7 & 43.7 \\
\hline
\end{tabular}

Table A.10. The content of n-paraffins and isoparaffins in the diesel fuel samples.

\begin{tabular}{|c|c|c|c|c|}
\hline \multirow[t]{2}{*}{ Diesel fuel sample } & \multicolumn{3}{|c|}{ Content of n-paraffins, $\%$ wt. } & \multirow{2}{*}{$\frac{\text { Content of isoparaffins, } \% \mathrm{wt} .}{\text { Total }}$} \\
\hline & Total & $\mathrm{C}_{16+}$ & $\mathrm{C}_{20+}$ & \\
\hline 1 & 20.77 & 7.79 & 2.71 & 25.23 \\
\hline 2 & 19.08 & 7.88 & 2.78 & 27.82 \\
\hline 3 & 19.61 & 8.88 & 4.01 & 24.59 \\
\hline 4 & 22.05 & 8.34 & 3.04 & 24.25 \\
\hline 5 & 19.88 & 7.14 & 2.32 & 23.82 \\
\hline
\end{tabular}

